\title{
Connecting with climate science
}

\author{
Protecting science-based policymaking requires engaging the public, not politicians. Cultural institutions \\ and the arts provide non-partisan platforms for communication that can connect scientific climate \\ change data to people's lives.
}

A rapid stream of policy changes and an unprecedented public reaction marked the first weeks of the Trump presidency. In response to signs from the Trump administration that they plan to muzzle government researchers, cut grant funding, and reverse science-based policies, a March for Science is being organized for Earth Day (22 April 2017) in Washington DC and around the world (http://go.nature. $\mathrm{com} / 2 \mathrm{kOWpXm}$ ). However, there are concerns that a March for Science will only reinforce the view held by sceptics that the research itself is politicized. Writing in The New York Times, coastal geologist Robert Young argued that to effect change, scientists need to work harder to communicate with the general public, not politicians, about the scientific evidence and how it relates to people's lives ${ }^{1}$. "We need storytellers, not marchers."

Incorporating climate change into cultural experiences can engage the public and change the conversation. In this issue's Feature (page 168), Sonja van Renssen explores the myriad ways the arts are being used to communicate the oftentimesabstract impacts of climate change and the underlying scientific data. For instance, photorealistic depictions of iconic coastal cities under $2{ }^{\circ} \mathrm{C}$ and $4{ }^{\circ} \mathrm{C}$ warming scenarios ${ }^{2}$ provoke stronger emotional responses than simply knowing that sea level rise could be between 7-10 metres; films that allow viewers to actually see a city's daily carbon emissions ${ }^{3}$ (pictured) and musical compositions based on climate data ${ }^{4,5}$ may better capture aspects of the data's meaning that are not easily grasped from a static scientific graph, like very large quantities or changes over time. These artistic renderings bridge the gap between knowing the facts and understanding them.

As museum advisor Morien Rees writes in a Commentary (page 166), "how and where communication is achieved is as important as what is communicated". He argues that museums are ideal venues to address the challenges of climate change communication because of their unique ability to foster dialogue across disciplines, making complex global issues locally relevant. For instance, his own museum

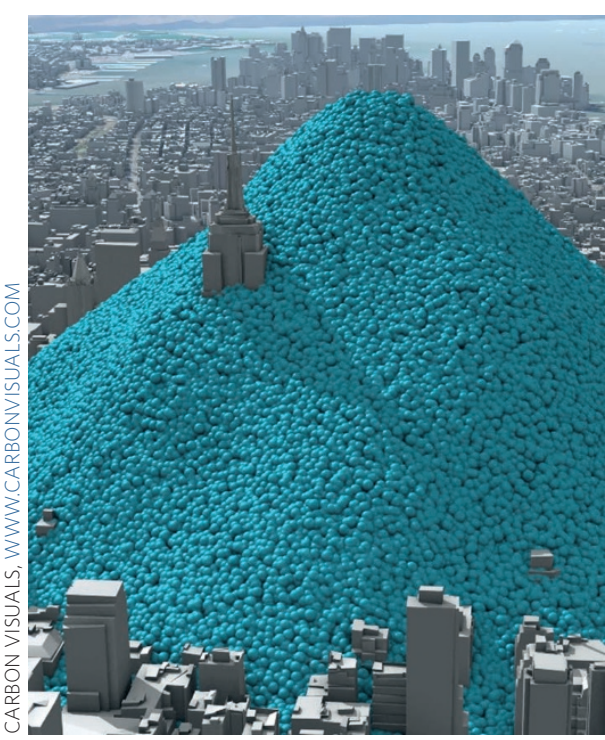

in Norway is working with climate researchers and national park rangers to create an exhibit within the Varanger Peninsula National Park (http://go.nature. com/2lPpY8P) to highlight the impact of climate change on park wildlife. In a similar vein, the Manitoba Museum in Winnipeg, Canada, has an award-winning exhibit (http://go.nature.com/2ksDwG0) that integrates virtual reality and video simulation technology and pure water science to draw attention to the problems facing Lake Winnipeg due to climate change and the actions required to save it.

Climate change is often presented as an issue for scientists and policymakers, which can make it easy for the public to remain disconnected. Both van Renseen and Rees discuss ways in which cultural experiences of climate change can complement major international policy and scientific events to turn passive observers into active participants. For example, van Renssen highlights ArtCop21, a global climate art festival that included 551 cultural events and exhibits across 54 countries in the four months preceding the $2015 \mathrm{UN}$ climate conference. These musical, literary, theatrical, and visual arts events connected people to the climate problem and the importance of the Paris meeting. Rees proposes that a similar international event should accompany publication of the next IPCC report. Rather than passively learning about the contents from traditional news media, the public could be provided with opportunities to actively engage with the report content through a coordinated global dissemination project designed and executed by the international museum sector. Indeed, the museum sector already has a cooperative international infrastructure in place that can be mobilized to this end.

The communication divide between scientists and the public, and the influence of political ideology on perceptions of science, is not limited to research topics like climate change that are themselves politically polarizing ${ }^{6}$. For example, a 2016 poll conducted by Research!America (http://go.nature.com/2kpbyQr) found that $81 \%$ of respondents could not name a living scientist. \#actuallivingscientist subsequently went viral on 3 February 2017 and was used by scientists to explain who they are and what they do in 140 characters. While it seemed to respond to the problem of people lacking awareness of scientists, it is not clear that this has done more than unite the scientific community - people who do not know a living scientist are unlikely to be following one on social media. This falls short of the personal public engagement that Robert Young envisions, and does little to overcome the perception that climate change is a partisan issue. Museums and galleries provide impartial platforms to disseminate climate and science messages beyond the echo chamber, but scientists can contribute by thinking about new ways to make their data accessible and personally meaningful. $\square$

\footnotetext{
References

1. Young, R. S. A Scientists' March on Washington Is a Bad Idea. The New York Times (31 January 2017); http://go.nature, $\mathrm{com} / 2 \mathrm{kOIjF9}$

2. Strauss, B. Images Show Impact of Sea Level Rise on Global Icons. Climate Central (8 November 2015); http://go.nature. com/2leQnzF

3. New York's Carbon Emissions (Real World Visuals, 2014); http://go.nature.com $/ 2 \mathrm{kSw} 4 \mathrm{bC}$

4. Hickey, $\mathrm{H} . \mathrm{CO} 2$ record at Mauna Loa, the music video: The sounds of climate change. UWTODAY (30 September 2016); http://go.nature.com/2lffmTy

5. St. George, S., Crawford, D., Reubold, T. \& Giorgi, E. Bull. Am. Meteorol. Soc. http://doi.org/bzng (2017).

6. Broomell, S. B. \& Kane, P. B. J. Exp. Psychol. Gen. 146, 286-304 (2017).
} 